\title{
МОВНА СИТУАЦІЯ В ПРИДНІСТРОВ'ї (НА ПРИКЛАДІ ФУНКЦІОНУВАННЯ УКРАЇНСЬКОЇ МОВИ)
}

\author{
ОКСАНА ПОПЧЕНКО \\ Українська середня загальноосвітня школа № 1, Рибниця - Придністров’я \\ JEZZYKOWA SYTUACJA W NADDNIESTRZU \\ (NA PRZYKŁADZIE FUNKCJONOWANIA JĘZYKA UKRAIŃSKIEGO) \\ OKSANA POPCZENKO \\ Ukraińska ogólnokształcąca szkoła średnia nr 1, Rybnica — Naddniestrze
}

STRESZCZENIE. W artykule zaprezentowane zostały główne postulaty teorii sytuacji językowej zawarte w pracach rodzimych i zagranicznych językoznawców. Przeprowadzona została analiza stopnia funkcjonowania i rozwoju języka ukraińskiego w Naddniestrzu, określone zostały charakterystyczne cechy współczesnej sytuacji językowej w regionie.

\section{THE LANGUAGE SITUATION IN TRANSNISTRIA (BASED ON FUNCTIONING OF THE UKRAINIAN LANGUAGE).}

\author{
OKSANA POPCHENKO \\ Ukrainian Comprehensive School \# 1, Rybnitsa - Pridnestrovie
}

ABSTRACT. The article focuses on the analysis of the main aspects of the theory of the language situation in the works of native and foreign linguists, the analysis of the degree of functioning and spreading of the Ukrainian language in Transnistria has been made, the characteristic features of modern linguistic situation have been determined in the republic.

$\mathrm{M}$ овна ситуація - один 3 найважливіших об'єктів соціолінгвістики. Висвітленню проблеми мовної ситуації в сучасній соціолінгвістиці присвячені праці В. Авроріна, Б. Журковського, О. Кондрашкіної, Л. Крисіна, Л. Нікольського, О. Швейцера та ін.

За визначенням В. Брицина, мовна ситуація - це „притаманний суспільству спосіб задоволення комунікативних потреб за допомогою однієї чи кількох мов"1. О. Швейцер та Л. Нікольський характеризують мовну ситуацію як ,систему соціально й функційно розподілених мовних систем і підсистем, що співіснують і взаємодіють у певній етнічній спільноті або в певному адміністративно-територіальному об'єднанні і в ставленні до яких члени відповідних мовних і мовленнєвих колективів дотримуються певних соціальних настанов"2. Мовна ситуація не може бути постійною, вона змінюється завдяки як об'єктивним чинникам, тобто таким, що не залежать від людської свідомості, так і суб’єктивним, що пов’язані зі свідомою людською діяльністю). В. Чернишов запропонував докладну характеристику об'єктивних і суб'єктивних чинників, від яких залежить мовна ситуація на певній території. На його думку,

${ }^{1}$ Украӥнська мова. Енщиклопедія, редкол. В. М. Русанівський, О. О. Тараненко та ін., Київ 2000 , с. 332.

2 А. Д. Швейцер, Л. Б. Никольский, Введение в сощчилингвистику, Москва 1978, с. 102. 
до об'єктивних чинників належать лінгвістичні (лінгвістичний склад населення, кількість мов, що є засобами комунікації, відмінність між мовами та між мовами й діалектами, що забезпечують взаєморозуміння), культурно-історичні (єдність або відмінність матеріальної та духовної культури, наявність або відсутність літературної традиції), демографічні (кількість носіїв мови або діалекту, компактність їхнього проживання, рух населення), географічні (фізикогеографічний ландшафт, наявність або відсутність перешкод, що заважають контактам), економічні (товарно-грошові стосунки, розвиток місцевих ринків і наявність загальнонаціонального), соціально-історичні (класове розшарування суспільства, характер суспільно-економічної формації, масові міграції, історичні зміни). До суб'єктивних чинників, на думку В. Чернишова, належать соціологічний і політичний ${ }^{3}$.

Отже, мовна ситуація - сукупність форм існування однієї мови або сукупність мов у їх територіально-соціальному взаємовідношенні й функціональній взаємодії в межах певних географічних регіонів або адміністративнополітичних утворень. Іншими словами, це взаємовідношення використовуваних на певній території різних мов чи різних мовних варіантів. Мовна ситуація охоплює соціальні умови функціонування мови, сферу й середовище вживання мови, форми іï існування.

Мовну ситуацію описують за кількісними, якісними й оцінними критеріями. До кількісних ознак належать:

- кількість мовних утворень, що співіснують на досліджуваній території. Це може бути кілька мов, а в межах однієї мови - певна кількість діалектів, говірок, інших форм існування мови — літературної і не літературної;

- кількість мовців, які користуються кожною мовою або формою існування однієї мови, стосовно загальної чисельності населення ареалу, що досліджується. Цей показник визначає демографічну потужність мови;

- число комунікативних сфер, які обслуговує кожна мова або форма існування однієї мови.

Якісними критеріями $є$ :

- характер мовних форм: різновиди однієї мови чи різні мови (одномовність і багатомовність);

- структурно-генетичні відношення між мовами (споріднені й неспоріднені, морфологічний тип мови);

- функціональна рівнозначність - нерівнозначність мов;

- характер панівної мови (місцева чи іноземна).

Під оцінними критеріями розуміють внутрішню й зовнішню оцінку мов. Внутрішня оцінка — це оцінка споконвічними носіями мови іiі комунікативної придатності, естетичної престижності, тобто ступінь прихильності мовців до рідної мови. Зовнішня оцінка - це характеристика названих параметрів мови носіями інших мов. На основі цих критеріїв будується типологія мовних ситуацій. Щоправда, оцінне поняття „престиж”, що нині широко використовується, зокрема й у працях американських соціолінгвістів, не має чіткого визначення. Так, Джон Фішман налічує п'ять різних значень цього терміна, до яких належить: комунікативна цінність, літературно-культурні досягнення, емоційна цінність, загальна повага, загальна популярність.

Мовні ситуації поділяють на прості (одномовні) і складні (багатомовні). Одномовні ситуації ще називають ендоглосними, а багатомовні - екзоглос-

${ }^{3}$ Е. А. Кондрашкина, Индонезия: языковая ситуащчия и языковая политика, Москва 1986, c. $16-17$. 
ними. У випадку ендоглосної ситуації мовець залежно від середовища користується то літературною мовою, то говіркою, а в разі екзоглосної - різними мовами.

Із екзоглосних ситуацій найпоширенішою є двомовність, або білінгвізм. При білінгвізмі дві мови співіснують у межах одного колективу, який користується двома мовами в різних комунікативних сферах залежно від соціальної ситуації та інших параметрів комунікативного акту. Крім двомовності, трапляються непоодинокі випадки тримовності, рідше чотиримовність і навіть п’ятимовність.

У країнах, де поширені дві або кілька мов, для вивчення мовної ситуації важливо визначити ступінь поширеності кожної мови, а також їхні оцінні характеристики. Існують два головних показники потужності мов: показник демографічної потужності, що визначається за кількістю носіїв певної мови стосовно загальної кількості населення території, що досліджується, та показник комунікативної потужності мови, що визначається за кількістю комунікативних сфер, які обслуговує кожна мова.

Особливо важливою для виживання мови за умов конкуренції двох або кількох мов у одній країні $є$ її комунікативна потужність. За цим параметром мовні ситуації поділяють на рівноцінні й нерівноцінні. За рівноцінної мовної ситуації обидві мови мають однаково сильну комунікативну потужність. Прикладом може бути мовна ситуація Бельгії, де співвідношення французької й нідерландської мов приблизно однакове. Нерівноцінну мовну ситуацію спостерігаємо в країнах Західної Африки. Тут місцеві мови переважають за показником демографічної потужності, але поступаються європейським за комунікативною потужністю.

Різноманітність мовних ситуацій у світі нескінченна. Відомі ситуації, де мовою міжетнічного спілкування є мова меншості (суахілі в Танзанії, малайська мова в Індонезії), запозичена мова (латина у Західній Свропі в середні віки, арабська в Середній Азії в VIII-X ст.), мови колишніх метрополій (англійська в Гамбії, Гані, Кенії, Нігерії, французька в Заїрі, Конго, Малі, португальська в Анголі, Гвінеї-Бісау, Мозамбіку). У деяких регіонах мовами міжетнічного спілкування є піджини: піджин-інгліш, лінгва-франка, біч-ламар та інші гібридні мови, що поширені на Далекому Сході, в Океанії, Західній Африці та Латинській Америці.

Вивчення мовної ситуації дуже важливе для вироблення правильної мовної політики. Мовна ситуація Придністров’я потребує грунтовного соціолінгвістичного аналізу за всіма релевантними показниками. Враховуючи їі асиміляційну специфіку, ключовою є проблема взаємовпливу на території республіки трьох мов - української, російської і молдавської. Внаслідок попередніх асиміляційних процесів мовна ситуація Придністров'я деформована, оскільки мова корінних і найчисельніших націй республіки (української та молдавської) на значній території витіснена мовою російською. Співвідношення україномовної, молдавськомовної та російськомовної частин населення не відповідає співвідношенню українців, молдован і росіян на їі території. Офіційних даних щодо співвідношення носіїв української, молдавської і російської мов за останнім переписом населення, проведеним в Придністров'ї в 2004 році, на сьогодні немає ${ }^{4}$.

${ }^{4}$ Итоги переписи населения Приднестровской Молдавской Республики 2004 года, в 5 тт., Тирасполь 2005. 
Щодо однієї із титульних націй — українців, то їх у Придністров'ї мешкає 150,5 тисяч, що становить 28,8 \% (загальна кількість населення Придністров'я в 2009 р. склала 522,5 тисяч осіб) 5 .

Причому найбільше їх проживає в м. Рибниця та Рибницькому районі 37554 осіб, що становить 45,41\% від загальної кількості населення в місті та районі, та в Кам'янці та Кам'янському районі - 11610 українців, 42,6\%. В Тирасполі 52481 українців, що складає 33\% від загальної кількості населення міста. В Дубоссарах та Дубоссарському районі українців 10594 особи -28,3\% від загальної кількості. В Слободзеї та Слободзейському районі 20772 українця - 21,7\%. Найменше українців мешкає в Бендерах - 18725 осіб, 17,8\% від загальної кількості населення міста; в м. Григоріополі та Григоріопольському районі мешкає 8333 українця, що складає 17,4 \% ${ }^{6}$.

За даними перепису населення 2004 року українців серед міського населення 112919 осіб - 30 \% від загальної кількості міського населення. В селах мешкає 47150 українців, що складає $26,5 \%{ }^{7}$.

Зазначимо при цьому, що процес денаціоналізації українців триває. Попередні переписи фіксували послідовне зменшення в українській спільноті осіб, які вважають рідною українську. Так, згідно з переписом 1959 р., українську мову вважали рідною 86,3\% українців МРСР, в 1970 р. — 79,4\%, в 1979 р. -68,5\% ${ }^{8}$.

Росіяни становлять одну із найчисленніших титульних націй - їх мешкає в Придністров'ї 158,8 тисяч, що складає 30,4 \% ${ }^{9}$. Для абсолютної більшості росіян рідною лишається своя мова.

Молдован в Придністров'ї мешкає 166,8 тисяч, що складає $31,9 \%{ }^{10}$. Для абсолютної більшості молдован, як і для росіян, рідною лишається молдавська мова.

Отже, на сьогодні в Придністров'ї склалася тримовна ситуація, що наближається до рівноцінної, - кількісні показники поширення української, молдавської і російської мов свідчать про однаково сильну демографічну потужність цих мов, хоча вони по-різному проявляються в різних місцевостях. Одначе така рівноцінність притаманна мовній ситуації на рівні демографічної потужності. На рівні ж комунікативної потужності ситуація інша, а саме: у більшості сфер спілкування тією чи тією мірою переважає російська мова.

На жаль, крім соціолінгвістичного дослідження „Мовна ситуація і мовна політика (російська мова в Придністров’і)”, проведеного в 1998-2002 рр. К. Погорєловою, інших розвідок не проводилось. Можемо навести лише певні вибіркові дані за результатами дослідження, здійсненого Т. Лозан у 2003 та 2010 роках під керівництвом О. Хорошковської.

5 Статистический ежегодник Приднестровской Молдавской Республики-2011: Статистический сборник (за 2006-2010 гг.), государственная служба статистики министерства экономики ПМР, Тирасполь 2011.

${ }^{6}$ Итоги переписи населения Приднестровской Молдавской Республики 2004 года, в 5 тт., Тирасполь 2005.

7 Там само.

8 А. Нікітченко, Лінгводидактичні умови навчання української мови в загальноосвітніх закладах Республіки Молдови, Київ 2004.

${ }_{9}$ Статистический ежегодник Приднестровской Молдавской Республики-2011: Статистический сборник (за 2006-2010 гг.), государственная служба статистики министерства экономики ПМР, Тирасполь, 2011.

10 Там само.

11 Там само.

12 Там само. 
Соціолінгвістичні дослідження в Придністров’ї лише починають розгортатися, для глибокого і всебічного аналізу мовної ситуації в різних регіонах республіки потрібні додаткові неодноразові анкетування.

Проведені анкетування засвідчують таке небезпечне для майбутнього української мови явище, як спад активності побутування іiї серед членів однієї сім’ї різного віку в напрямі: старше покоління — молодше покоління. У групі українців, які вважали українську мову рідною, вона переважала в спілкуванні з батьками.

Велику небезпеку для майбутнього української мови становив також показник зміни ступеня активності користування нею в групах українського населення, що виділялася за віком і освітнім чинниками. Падіння участі української мови як засобу спілкування всередині цих груп відбувалося в напрямі: старше покоління - молодше покоління і середня освіта — вища освіта.

Серед дітей дошкільного віку на кінець 2009 року українською мовою навчалися лише 116 осіб - 0,58\% від загальної кількості дошкільнят республіки. Функціонує всього дві школи з українською мовою навчання (м. Рибниця та м. Тираспіль) та 53 російсько-українською мовами навчання. Показник навчання українською мовою знижується, зокрема в 2005-2006 н. р. українською мовою навчалося 0,8 тисяч школярів, а в 2009-2010 н. p. - 0,4 тис. Навпаки, кількість школярів, що навчається російською і українською мовами збільшується. Так, в 2005-2006 н. p. їх 1,6 тис., а в 2009-2010 н. р. - 1,7 тис. Звичайно, показники набагато нижчі проти показників щодо кількості освітніх закладів з російською, молдавською та російсько-молдавською мовами навчання. Російських шкіл на кінець 2010 р. - 114, молдавських - 33, російськомолдавських - 12. Відповідно кількість учнів в російських - 39,1 тис., молдавських - 5,5 тис., російсько-молдавських — 2,9 тис. ${ }^{11}$

Як другу офіційну, українську мову вивчають близько 16 \% школярів. ${ }^{12}$

Спостерігаємо невтішні показники щодо навчання українською мовою в закладах початкової, середньої та вищої професійної освіти. Так, на кінець 2010 р. серед студентів вишів українською мовою навчаються 1,5\%, в закладах середньої професійної освіти та початкової професійної освіти українською мовою не навчаються.

Отже, за показниками комунікативної потужності мовна ситуація в Придністров'ї є нерівноцінна.

Порівняльні дані щодо динаміки розвитку мовної ситуації Придністров’я за роки опитувань засвідчують, що в різні роки зміни в поширеності української мови відбувалися по-різному. Найчисельнішим лінгвосоціумом у складі населення Придністров'я були й залишаються російськомовні етнічні росіяни.

Дослідження засвідчує значні розбіжності у використанні української, молдавської і російської мов залежно від типу населеного пункту. Найбільшу прихильність до української та молдавської мов виявляють сільські мешканці, вони ж найчастіше використовують іiі у сімейному спілкуванні. Щодо міського населення, то тут спостерігаємо таку закономірність: що більше місто, то менше його мешканців визнає українську мову рідною і ще менше використовує їі в сімейному спілкуванні.

Для вивчення стану українського мовлення в умовах багатомовного середовища в 2003 році Т. Лозан провела соціологічне вивчення мовлення українців Рибницького регіону, визначивши типові помилки в їхньому мовленні, їх характер і причини. 3 цією метою було вивчено історію поселення українців в Придністров $\dddot{1}$, зроблено аналіз мовлення українських сімей, проведено анкетування, спостереження, бесіди. Наведемо дані цього дослідження. 
Матеріали дослідження засвідчують, що в Рибниці склалась особлива мовна ситуація, причини якої зводяться в основному до такого:

- наявність домінуючої російської мови;

- відсутність безпосереднього контакту українців 3 носіями української літературної мови;

- спілкування в сім'ях нерідко двома мовами, оскільки з'явилось багато етнічно змішаних шлюбів.

На українську мову вплинув ще й такий чинник, як національна багатобарвність. У зв'язку з цим на сьогодні в Рибниці переважно українсько-російська та російсько-українська двомовність, інколи — тримовність.

Отже, аналіз мовної ситуації показує, що сьогодні в м. Рибниці та Рибницькому регіоні побутує білінгвізм. Анкетуванням було охоплено 250 осіб. Цікаво, що 70\% респондентів мають прізвища українського походження. Як показує дослідження, переважна більшість респондентів є етнічними українцями (78\%), вважає українську мову рідною $(50 \%)$, до української мови ставиться добре (56\%). Визначення побутування української мови в сім'ях показали, що українською мовою розмовляють 3 дітьми $36 \%$ батьків, дома, 3 товаришами і знайомими відповідно 42,5 і 53\%. Слухають радіо та дивляться телепередачі українською мовою $65 \%$ опитуваних. Найчастіше в сім'ях українською мовою користуються члени сімей старшого покоління - дідусі, бабусі (45\%). Цей факт, свідчить про те, що старше покоління менш зачепила русифікація i їхній мовний режим залишився сталим, тобто українським. Визначення діапазону періодів проживання теж показав, що, хто проживав в м. Рибниці в 70-80-х роках XX ст. (46\%), в побуті користується лише українською, а хто з 80-х років - то “змішаною” мовою, тобто суржиком.

Порівняння частотності використання української та російської мов засвідчило, що українською мовою користуються рідше, насамперед у сімейному побуті, однак на роботі і в міському побуті - лише російською.

Всі ці факти дають підстави дійти висновку про те, що українська мова не $\epsilon$ пріоритетною в мовній свідомості і мовленнєвій практиці означеного контингенту, однак українську мову використовує значна кількість етнічних українців як другу функціональну.

У 2010 році анкетування охопило близько 300 осіб українського походження. Респондентами стали учні, студенти та інші жителі міста Рибниця. Загалом, анкетування показало, що $87 \%$ респондентів є етнічними українцями. $63 \%$ респондентів навчаються, а отже, мають більше можливостей стикатися 3 українською мовою. Майже третина опитаних користується українською мовою в міжособистісному спілкуванні. Одна шоста частина опитаних використовує українську мову в громадському житті і лише одна восьма частина - у культурній діяльності. Наведені показники свідчать про низький рівень побутування української мови. Ці показники підтверджують і ті факти, що половина респондентів соромиться української мови: лише $18 \%$ спілкується українською.

У сфері освіти комунікативна потужність української мови виявилася найбільш сильною. Тут перевагу українській мові надають $36 \%$ респондентів. У міжособистісній сфері - $25 \%$, у сфері обслуговування - $15 \%$, у сфері масової комунікації - $11 \%$. Низьку комунікативну потужність українська мова має у сфері культури, мистецтва та науки $-8 \%$, в офіційній сфері $-5 \%$.

Дослідження теоретичних та практичних надбань учених, проведений аналіз даних переписів й опитування щодо побутування в різних сферах україн- 
ської мови дало змогу проаналізувати сучасну мовну ситуацію в Придністров'ї, що протягом тривалого часу характеризує українсько-російська двомовність, яка має такі диференційні ознаки:

1) домінувальною на території Придністров'я є російська мова;

2) демографічна потужність української, молдавської та російської мов на досліджуваній території наближається до рівноцінної;

3) щодо комунікативної потужності мов, то тільки російська мова присутня в усіх сферах життя, наприклад, в офіційній сфері майже зовсім відсутні українська та молдавські мови;

4) ситуація двомовності, яку простежуємо на території Придністров’я, не означає рівноправності української, молдавської та російської мов на офіційному рівні.

Отже, здійснений аналіз мовної ситуації на території Придністров’я крізь призму кількісних і якісних характеристик засвідчує, що українська мова ще не отримала належного застосування в усіх сферах життя, хоч останні дослідження засвідчують прогнозоване розширення сфер вжитку української мови. Аспект такого розширення вимагає додаткового аналізу не тільки в соціолінгвістичному, а й психолінгвістичному плані.

Сучасну мовну ситуацію в Придністров’ї характеризує поширення контактного різновиду білінгвізму, при якому існує безпосередній зв'язок між носіями української та російської мов. Білінгвальна традиція й мовна політика зумовлюють складний механізм формування індивідуальної двомовності. Українська мова залишається мовою неповного етнічного поширення й поступається російській за показником комунікативної потужності, який визначає повнота сфер використання мов.

Отже, ознакою деформованого мовного простору Придністров'я є поширення мішаних українсько-російських форм усного мовлення, відомих як суржик. Суржик пов'язують із низькою мовною й комунікативною компетенцією мовців. Він постає внаслідок намагань україномовних громадян пристосуватися до російськомовного оточення, тому має перехідний (від української до російської одномовності) характер - хаотичне змішування елементів двох мов.

У сучасному Придністров'ї мовне буття особистості частіше не пов'язане з їі етнічною самоідентифікацією. Оскільки етнофорам (носіям основних етнічних рис) не притаманна усталена мовна поведінка (принаймні у виборі мови спілкування), аналіз міжлюдської взаємодії потребує залучення історичних, психологічних, соціологічних знань. Це стосується тією чи тією мірою як українців, так і українських громадян інших національностей.

Здійснений аналіз змушує визнати необхідність вироблення відповідної мовної стратегії (і всієї культурної) політики в Придністров’ї, що сприяла б толерантній взаємодії спільнот із різними ідентичностями. Важливе значення має впровадження української мови в культурно-інформаційний простір Придністров’я. Українська мова, культура, національні традиції повинні знайти ефективні форми популяризації на телебаченні, радіо, в друкованих засобах інформації із залученням наукової та творчої інтелігенції. 